\title{
CONVERGENCE IN THE EUROPEAN UNION
} FROM THE ASPECT OF DEVELOPMENT ECONOMICS ${ }^{1}$

\author{
Comments to a collection of studies by Michael Landesmann \\ and István P. Székely
}

István Ábel

\begin{abstract}
A collection of papers published in two volumes by Landesmann-Székely (2021) is the analysis of the process, achievements, and problems of the convergence of 11 countries (including Hungary) joining the EU in 2004 analysed in studies by 36 acknowledged experts of the region and the area. The studies cover vital issues of the present displaying a high standard of professionalism while they provide nonprofessional readers with a clear and convincing description of the region and the special problems of the countries constituting it.
\end{abstract}

1 This study was prepared in the MTA-BGE Macroeconomic Sustainability Research Group with the support from the Office for Research Groups Attached to Universities and Other Institutions of Eötvös Loránd Research Network

2 Michael Landesmann - István P. Székely (eds.) (2021): Does EU Membership Facilitate Convergence? The Experience of the EU's Eastern Enlargement. (Volume I-II). Studies in Economic Transition, London: Palgrave, Macmillan.

3 István Ábel, Professor, Budapest Business School. E-mail: Abel.Istvan@uni-bge.hu. 


\section{DEVELOPMENT AND CONVERGENCE}

The period looked at (1990-2017) was a success story for the EU-11 countries as they utilised global trends for development to their benefit if you compare their results to those of other regions (Figure 1)

\section{Figure 1}

\section{Economic and social convergence}

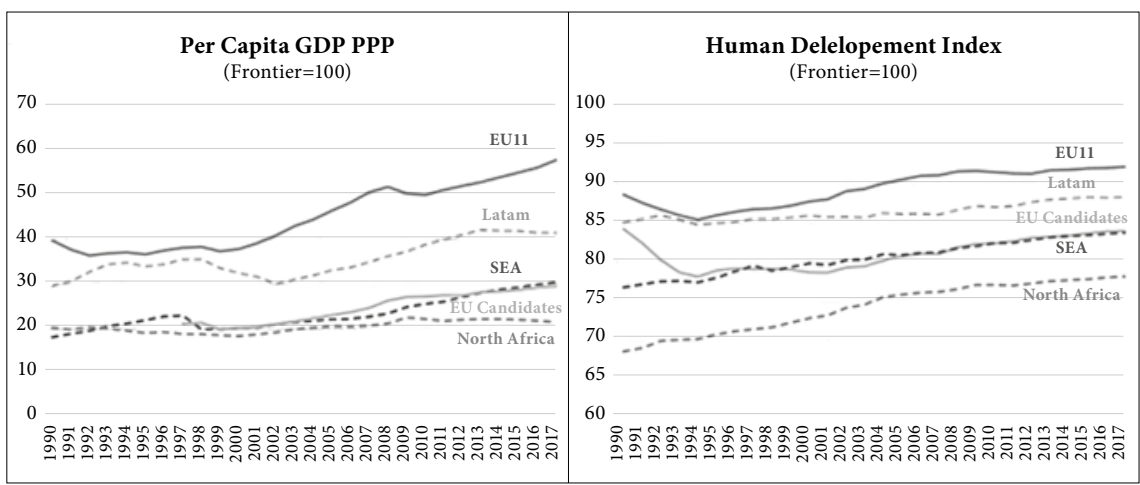

Source: Landesmann-Székely (2021:37)

Note: EU-11 countries: Bulgaria, Czech Republic, Estonia, Croatia, Poland, Latvia, Lithuania, Hungary, Romania, Slovakia, and Slovenia. Latam: Argentina, Chile, Costa Rica, Uruguay, North-Africa: Algeria, Jordan, Morocco, Tunisia. SEA: Indonesia, Korea, Malaysia, Philippines.

In the book, convergence is compared prudently not to the EU average but to global frontier countries that are relevant for the region. They are Austria, Denmark, the Netherlands, and Sweden. Readers are given a detailed and differentiated image of the process by presenting the economic, social, and institutional dimensions of convergence achieved in the period studied as well as their interactions and connections. In that way, the improvement of social factors (ends) is presented as the outcome of economic development (means) countries achieved following often individual paths of institutional restructuring (ways). Special emphasis is given to the introduction of the characteristic features of justice and sustainability as their significance is increasing in our age. The authors studied the relationship of the complex process of development integrated into a single frame. The detailed analyses of different factors presented separately convincingly support the approach used. Readers are provided a picture of the main drivers of integration with separate analyses of the features of trade, investments, funding movement of labour and institutional systems. They, at the same time, represented key channels of integration interacting to exert their influence on convergence as part of the integration.
In his comment recommending the book, Vito Tanzi calls attention to the prudent approach to the development of the EU-11 countries saying:

"The main message in the book, perhaps not a surprising one, is that, joining the EU gave the EU11 access to a large market and to a lot of foreign investment. These contributed to their economic „growth”. Unfortunately, as the first development economists learned 70 years ago, and as many modern economists forgot, economic growth is not the same thing as development. Development depends on the existence of institutions that distribute widely the benefits of economic growth. The creation of these institutions is more difficult than the generation of growth because it depends on established cultural traits. In the EU11 countries, institutional or social development has lagged their growth. This is likely to create potential future problems."

The above remark by Vito Tanzi is an important message for us for two reasons, in addition to acknowledging the research findings published in the books we can confirm that they are meant to avoid the trap described. On the one hand, he emphasises the main message of the research findings should be a guidance on how to avoid the mistakes he attributes to the forgetfulness of „many modern economists" when growth is assessed, and economic policy proposals based on them are offered. Although the analyses in the book cover topical issues and are of a practical nature, the authors' informed and thorough work prevents them from being biased. At the same time, Vito Tanzi's benevolent warning raises, for me, the issue: what potential future guidance development economics, almost obsolete by now, may provide for the analysts of today in connection with this book. In this paper I'll use the paper by Reis-Cardoso (2020) as an overview of the numerous schools of development economics.

I should note at the outset that I have presented the following thoughts as critical remarks made on the book by Landesmann-Székely (2021), but the readers will see my remarks do not question their results in any way. Rather, my paper underlines the value of their research and my comments are not closely related to the analyses discussed and thoroughly presented in the book. My comments may raise issues that are related to the convergence of the EU-11 countries discussed in the framework of the traditional approach of development economics. To be more specific, let me say the book by Landesmann-Székely (2021) can be regarded as the formal application of the modern classical approach, while what I want to present here are critical remarks from the heterodox point of view. Still, I would like

\footnotetext{
4 Vito Tanzi's remark in the Recommendations on the cover of the book by LandesmanNSZÉKELY (2021).
} 
to be reasonably modest by saying I accept the findings of the book and intend to present some further considerations on their basis.

In this paper I am interpreting the integration of the EU-11 and the process of convergence of developing countries in which the initial conditions vary, and circumstances continually change in light of an analogy with the wider problem of centre and periphery in their economic and political treatment and their development process. Of course, all analogies are false as soon as stated, but the issue of centre and periphery and the comparison of the EU-11 integration may include useful simplifications applied in the process of the analysis that help to clarify the problem itself.

\section{THE MESSAGE OF THE KALECKI SCHOOL}

\section{OF DEVELOPMENT ECONOMICS}

As seen in Vito Tanzi's remark quoted above, the classics of development economics dealt with the problems of a period well seventy years ago. Kalecki was one of the classical development economists. He stated that unemployment and under-employment in less developed countries were the result of limited production capacities and could not be explained by a temporary shortage of demand. Further, he warned that demand increasing with industrialisation would lead to inflation unless production capacities and producers' productivity could grow side by side with the increase of demand for agricultural and food industry products. He said increasing investment was key not only to increase productivity and efficiency but also to enhance production capacities. He emphasised three elements as constraining factors to development and investments. Development economists earlier regarded the insufficient investment activity of the private sector and the limited resources to be used to produce capital goods to be the key stumbling blocks of development. According to Kalecki, even if the problems of the above two factors had been treated by accelerated growth, increasing demand for agricultural products going hand in hand with increasing incomes would have caused inflation. Contrary to reformers emphasising industrialisation, Kalecki underlined the necessity of agricultural reforms (Reis-Cardoso, 2021:174-175).

Readers may be right to ask why I mention this old problem, since all three conditions have been met through the successful development and convergence of the EU-11 countries following their 2004 accession to the EU. The EU offered wide range of capital goods required for private investments and technological development. The productivity of the agricultural sector reached the level of more developed countries in most places, so that could not be an obstacle either. Still, Kalecki's approach can be a warning sign from one aspect. The fall of Commu- nism in the acceding countries triggered privatisation and institutional changes in the agrarian sector and the food industry processing the former's products, which were carried out in such a way that resulted in the deterioration of previously reached levels in the medium and long run. Agricultural subsidies from the EU counteracted that effect for a long time. However, provided the system of agricultural subsidies changes in the future, one must be prepared to face difficulties slowing down further development and convergence. Pinelli - Pellényi (2021) touch upon those problems in Volume I from a slightly different angle as they provide a detailed analysis of regional dynamics.

\section{THE PREBISCH-SINGER HYPOTHESIS AND THE TERMS OF TRADE}

Raúl Prebisch the highly influential founder of development economics offered noteworthy hypotheses on the consequence of comparative advantages in periphery catching-up countries. According to the principle of comparative advantages, countries having different supplies of resources can turn their characteristics into an advantage via foreign trade, so they can have an equal share of the benefits of technological innovation used in production. Thus, in periphery countries it is worth specialising in agricultural production, which is sufficiently available, and it is not necessary to push industrialisation in development policies. In real life, however, periphery countries cannot protect themselves from the impact of cyclical fluctuations triggered in the developed countries by technological development. The Prebisch-Singer hypothesis clarified that problem. The authors start out by stating that periphery countries mainly export basic products, raw materials, and agricultural products to industrialised countries while the latter mostly export industrial products of an advanced stage of manufacture. According to the hypothesis drawn from an analysis of trade data, industrialised countries can use their savings achieved by technological development to pay higher wages and increase their profits. In other words, they retain them by means of trade agreements and institutions. On the other hand, the workers and enterprises in periphery countries cannot appropriate the profits gained from technological development, as they materialise in lower prices and lead to the deterioration of terms of trades (Prebisch, 1950, 1959, Singer, 1950). Hatvey et al. (2010) seem to corroborate the hypothesis using longer time series and state-of-the-art econometric methodology. The paper by Szabo-Laguna (2021) also deals with the problem in detail and provides an overview of the debates generated about it in some EU-11 countries (Landesmann-Székely, 2021, II:49-52). 


\section{GLOBAL VALUE CHAINS}

\section{AND INTERNATIONALISATION OF FIRMS}

The proliferation of global value and supply chains and the internationalisation of firms in the 1980s marked the beginning of a new era of economic convergence. The process reshaped the operation of markets; markedly new elements appeared in the organisation of production. New financial instruments also appeared since a domestic enterprise integrated into a value chain had access to financing from its parent company with better conditions than what could be expected from the domestic banking system or the much less developed domestic capital market. The process also changed the relationship of centre and periphery. Development outlooks became defined by a company's position in the economic complexity of production processes rather than by the traditional rules of commerce. In line with cost factors, certain elements of the production process were relocated in another country, and supply chains were controlled across borders. Thus, the traditional interpretation of comparative advantage lost it meaning. Technologically advanced activities or processes financed and controlled by global value chains emerged in periphery countries, which used to focus on basic materials and food production in the past, diversifying their often-one-sided structure of foreign trade. The earlier approach of development economics focusing on industrialisation has become obsolete.

The spread of global value chains opened new opportunities and reshaped ideas about development. Typically, centralised industrialisation was replaced by the provision of the conditions of competition, the protection of property rights and foreign investments and considerations related to the operation of economic policy schemes aimed to maintain macroeconomic stability, as development-supporting functions of industrial politics. Thus, the access of periphery countries to foreign markets improved and foreign investments flowed into them. According to the earlier paradigm of development economics, the issue of obstacles to industrialisation seemed to have been swept aside. However, as Milber-Winkler (2011) pointed out, joining the global value chains did not mean at the same time that the new sources of economic development would automatically promote social ascension through the operation of the market. The profits from increased productivity by using new opportunities offered by value chains were often pocketed by the foreign parent company controlling the value chain. Using the categories of development economics, the defining components of economic structures include natural resources, the production and transport infrastructure built on them, networks, and technologies. However, the impact of economic growth on social improvement is subject to the functioning of the relevant institutions, the provision of property rights, the educational system, the culture, and the political orientation of state administration. Analysing the process of the EU-11 integration, this important consideration is emphasised in several studies in Volume II of Landesmann-Székely (2021).

The classical thinkers of development economics believed the process of convergence mainly required the improvement of production capacities, the increase of demand, central support provided for the necessary investments or the increase of demand abroad and export orientation. The appearance of global value chains has shed new light on that. The protection of land and promoting the influence of domestic oligarchs might have been in accord with the need of industrialisation, but it conflicted with the value chains relying on foreign investment (Reis-Cardoso, 2021:184).

In addition to offering access to foreign markets, value chains ensure investments to improve technology and enhance capacities for development. They do even more, as it is in their interest in emerging countries to put in place economic policies that ensure macroeconomic stability. The stability of exchange rates may be less crucial, since one can evade the difficulties of exchange rate fluctuations by applying relevant financial operations and accounting.

Although the spread of global value chains and the integration of companies in emerging countries into them may, in theory, overcome the obstacles of development which have been identified in classical development economics, many questions remain. For instance, it is not clear how economic progress will promote social progress. Another open question is how advantages achieved will lead to wage increase or better living standards of those employed. Classical economics assumes the market will solve that automatically. Reality, however, shows that it is not true at all. Landesmann-Székely (2021) believe the problem is rooted in the institutional system.

Clarifying the connection between economic growth and social progress would be key, and the studies in the book represent a major step in that direction. They have documented that the traditional assumption that social progress will naturally move ahead with economic development is not guaranteed. We still need to find economic and political solutions to this issues that have remained unsolved. Several analyses have proved that higher wages and stricter social standards increase costs, but they will not deter investors or damage the competitiveness of exports (Milberg-Winkler, 2011:361). This is contrary to traditional theories of foreign trade, but one should give up the approach of comparative advantage, which is in their background, anyway. The clarification of theory, however, would not only be important to satisfy our curiosity, but because it could shed light on major issues of economic policies. A major step has been made forward in that regard thanks to the 39 authors publishing their papers in the book by Landesmann-Székely (2021) 


\section{ON THE CONVERGENCE OF THE HUNGARIAN ECONOMY}

Several case studies analyse the convergence stories of different countries in the book's two volumes. As for the Hungarian economy, some papers deal with one or another aspect, or you could say, the Hungarian economy, as a polypathological test case, has been given special attention in relation to all important issues. The paper by Boldizsár-Nagy-Kékesi-Rariga (2021) offers a remarkable analysis of the correlations of foreign trade, indebtedness, and financing. Czelleng-Vértes (2021) have analysed the impact of subsidies from EU funds, while Tóth-Hajdu (2021) have dealt with the issues of the institutional system and corruption. There is no special country study, instead, you should look at Figure 2 I took from the comprehensive overview by Jaksity et al. (2021).

You can see here that, despite a relatively good starting position and exceptionally favourable opportunities provided by the EU over the past 20 years, the rate of convergence to the EU average has only been lower in Croatia (HR) and Slovenia (SI) than in Hungary. Still, it should be noted that Croatia acceded to the EU later, while Slovenia was much closer to the EU average right at the start.

\section{Figure 2}

Percentage points of convergence to $\mathrm{EU}$ average

by new EU Member States from 2004 to 2020 (GDP per capita)

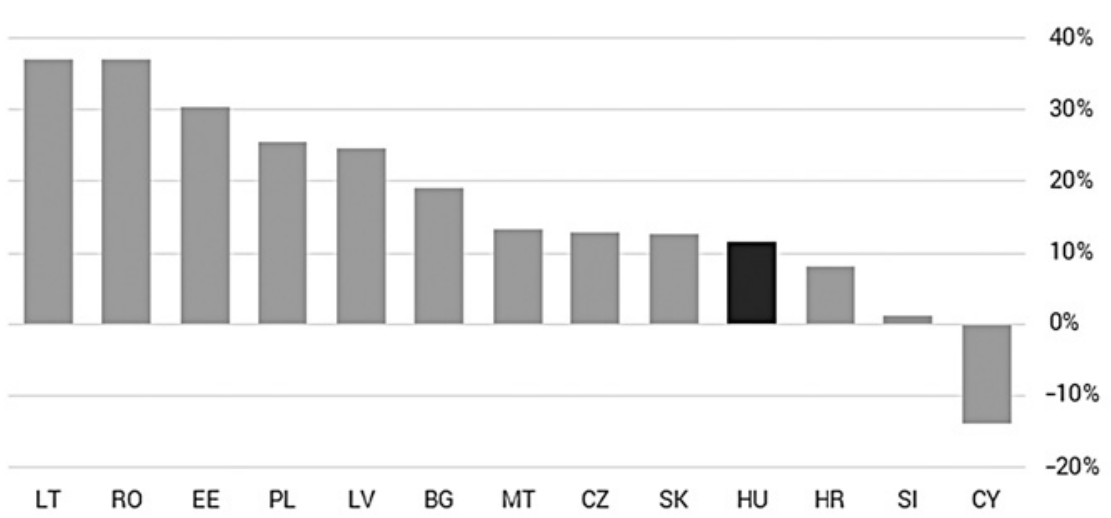

Source: Jaksity et al. (2021)

To sum up, let me add the work published in the two volumes is a treasure trove of information presented at high professional standards. I could discuss only some aspects in this comment. The editors have done a big and important job and the result is impressive.

\section{REFERENCES}

Boldizsár, ANNA - NAGy-KéKeSI, ZsuZsa - RARiga, ERZsébet-Judit (2021): Transformation of the Trade and Financing Model of the Hungarian Economy After EU Accession. In LANDESMANN-SZÉKELY (2021),Vol. I, 173-210.

Czelleng, Adam - Vertes, Andras (20231): The Impact of EU Cohesion Funds on Macroeconomic Developments in the Visegrád Countries After the 2008-2009 Financial Crisis. In LandesMANN-SZÉKELY (2021), Vol. II, 67-88.

Harvey, D. I. - Kellard, N. M. - Madsen, J. B. - Wohar, M. E. (2010): The Prebisch-Singer Hypothesis: Four Centuries of Evidence. The Review of Economics and Statistics, May, 92(2), 367-377.

Hermann, A. - Mouatt, S. (eds.) (2021): Contemporary Issues in Heterodox Economics Implications for Theory and Policy Action. New York: Routledge.

Jaksity György - JobbáGy SÁNDor - TunKLi DÁNIEL - MoHos Lilla (2021): Magyarország több sebből vérzik. Két évtized regénye. [Hungary facing a multiple crunch. The story of two decades.]. Portfolio.hu, 20 October. https://www.portfolio.hu/gazdasag/20211020/magyarorszagtobb-sebbol-verzik-ket-evtized-regenye-506266.

KALECKI, M. (1954): Theory of Economic Dynamics. An Essay on Cyclical and Long-Run Changes in Capitalist Economy. London and New York: Routledge.

KóNYA IstVÁN - KREKó JUDIT - OBLATH GábOR (2021): A bérhányad alakulása Magyarországon és Európában [Evolution of wages share in Hungary and Europe]. Közgazdasági Szemle, 68(10), 1021-1054.

Landesmann, Michael - Szérely, István P. (eds.) (2021): Does EU Membership Facilitate Con vergence? The Experience of the EU's Eastern Enlargement - Volume I-II. Studies in Economic Transition, London: Palgrave, Macmillan. DOI 10.1007/978-3-030-57686-8.

MILBERG, W. - WinKLER, D. (2011): Economic and social upgrading in global production networks: Problems of theory and measurement. International Labor Review, 150(3-4), pp. 341-365. https:// onlinelibrary.wiley.com/doi/10.1111/j.1564-913X.2011.00120.

Pineldi, D. - Pellényi, G. M. (2021): Regional Dynamics in EU-11. In Landesmann-Székel (2021): Vol. I, 123-148.

Prebisch, R. (1950): The Economic Development of Latin America and Its Principal Problems. Eco nomic Bulletin for Latin America, $7,1-12$

PREBISCH, R. (1959). Commercial Policy in the Underdeveloped Countries. American Economic Review, 49, 251-273.

ReIS, C. F. - CARDoso, F. G. (2021): Center and periphery in global value chains. An interpretation based on the pioneers of development. In HermanN - MouatT (eds.) (2021), 171-19o.

SINGER, H. (1950): The Distribution of Gains between Investing and Borrowing Countries. American Economic Review, Papers and Proceedings, 40, 473-485.

SZABo, S. - LAGUnA, J. D. (2021): FDI as Force of Convergence in the CESEE Countries. In LANDESMANN-SZÉKELY (2021), Vol. II, 37-66.

TOth IstVAn Janos - Ha)Du MiKLós (2021): Corruption, Institutions and Convergence. LANDESMANN-SZÉKeLY (2021): Vol. I, 195-248. 